\title{
In vitro seed germination of Cymbidium aloifolium (L.) Sw., a potential medicinal Orchid from Eastern Ghats of Tamil Nadu, India
}

\author{
Philip Robinson, J. • Jyoti Prasad Kakati $\cdot$ Sebastinraj, J. $\cdot$ Suriya K
}

Received: 1 November 2016 / Revised: 2 December 2016 / Accepted: 13 December 2016

(C) Korean Society for Plant Biotechnology

\begin{abstract}
Cymbidium aloifolium (L). Sw. is an exquisite epiphytic orchid of the Kolli Hills (Eastern Ghats) of Tamil Nadu in Southern India. It is fast disappearing from its natural habitats due to deforestation and low germination rate in natural habitat. In the present study, an attempt was made to germinate the seeds from un-dehisced capsule of Cymbidium aloifolium (L). Sw under in vitro condition. The seed germination and protocorm development were recorded in three different well known media namely Knudson C (KC), Half strength Murashige \& Skoog (1/2 MS) and Vacin $\&$ Went (VW) media. The highest seed germination of $90 \%$ was observed KC basal media after $30^{\text {th }}$ days whereas germination percentages were $40 \%$ and $30 \%$ on $1 / 2$ MS and VW media respectively. The well-developed protocorm were transferred to $\mathrm{KC}$ media supplemented with 6-Benzyl Amino Purine (BAP) and Naphthalene acetic acid (NAA) where BAP $(1.0 \mathrm{mg} / \mathrm{l})$ and NAA $(1.0 \mathrm{mg} / \mathrm{l})$ together were found to be optimum for the highest shoot formation. About $90 \%$ of the shoots found to be well rooted after transfer to the $\mathrm{KC}$ medium differently supplemented with $1.5 \mathrm{mg} / 1$ Indole3-acetic acid (IAA) and $1.0 \mathrm{mg} / 1$ Indole-3-butyric acid (IBA). Though rooting also took place in the two basic media but the duration was longer when compared with the hormone-supplemented media. The rooted plantlets were hardened and kept under greenhouse conditions which can be relocated in natural habitats.
\end{abstract}

Keywords Protocorm, Orchids, KC, 1/2 MS, VW media, NAA, BAP, IAA and IBA

Philip Robinson, J. $(\bowtie) \cdot$ Jyoti Prasad Kakati $\cdot$ Suriya K. Department of Biotechnology, K. S. Rangasamy College of Technology, Tiruchengode 637 215, Tamil Nadu, India e-mail: philiprobin81@gmail.com

Sebastinraj, J.

Department of Biotechnology, Jamal Mohamed College (Autonomous), Tiruchirappalli -620020, Tamil Nadu, India

\section{Introduction}

Orchids are outstanding in many ways, like diverse shapes, colors and its medicinal values. They are marketed both as plants and as cut flowers and their production has been increased in recent years due to demand in the floriculture field (Tokuhara and Mii 1993, 2001; Chang and Chang 2000). In vitro culture is an important tool to save the species which faces various threats and extinction (Hey and Hey 1966). It can undermine the capacity of many developing countries to conserve resources and meet basic human needs. Increasing pressures due to population on land and other natural resources can aggravate the intensity of natural disasters such as flood and drought. Depletion of the Earth's biological diversity has much more profound consequences than some other environmentally alarming. Owing to its horticultural significance, it is collected indiscriminately from the nature and as a result it is prone to vulnerable. The present study was undertaken with a view to develop and establish an efficient protocol for mass propagation and consequently commercial exploitation and conservation of this important indigenous orchid.

Hard and intelligent decisions are needed to save the valuable taxa from the vastly changing landscape. As part of an ex-situ conservation strategy, artificial propagation including micro-propagation is successfully employed for recovering certain other species having specific problems in conventional horticulture (Fay, 1994). The advantage of plant tissue culture for the conservation of endemic and endangered species lies in the fact that it makes use of small units without sacrificing ex-plant takes pressure off the wild populations and makes available large number of plants for restoration as well as for horticultural applications. Symbiotic germination methods were only used for a short time before being replaced by non-symbiotic germination procedures (Zeng et al., 2016). With non-symbiotic germination technology, thousands of seedlings could be raised to maturity from a single seed capsule. Besides the obvious potential in breeding, this technology is 
also extremely important for vegetative propagation (Griesbach, 2002, Naing et al., 2010). Propagation in- vitro has been successfully employed for the conservation of crop genetic resources, particularly with those crops which are vegetative propagated or possessing recalcitrant seeds, that cannot be stored under conventional seed bank conditions (Dodds, 1997, Villalolos et al., 1991, Wilkins et al., 1982, Paek et al., 2011)) while tissue culture is essentially used as a crisis management tool for the multiplication of the existing genotypes.

Cymbidium aloifolium (L). Sw. is an exquisite and medicinally important epiphytic orchid of the Kolli Hills (Eastern ghats) of Tamil Nadu in Southern India. The leaf extract of the plant is also traditionally used to treat ear ache (Syndhya et al., 2006). The leaf and root extracts are used to treat asthma and paralysis among the tribal peoples of Bangladesh (Mohammed et al., 2010, Naing et al., 2011). It is disappearing at a rapid rate from its natural habitats due to extensive collections by the orchid enthusiast. The plants produce very minute seeds and lacks endosperm. Wind acts as a vector for seed distribution and requires mycorrhizal association for their germination. Hence, a fast method of growing and conserving them in the green houses garners much attention.

In-vitro cultures of orchid seeds have shown that various species require different and often specific medium composition for optimum germination and growth. However, the sequential steps of development and histo-morphological changes from embryo to seedling have been traced only in a few species, including those of Vanda (Rao and Avadhani 1964), Cattleya (Shushan, 1959), Cymbidium (Vij, 1986) and Geodorum (Jon and Nirmalya, 2001).

Purpose of this article is to report our success in aseptic seed germination of Cymbidium aloifolium (L). Sw. and to trace the sequence of developmental changes that take place from the onset of seed germination and development of protocorm- like bodies (Plbs).

\section{Materials and Methods}

Preliminary assessment to select suitable medium for germination

The mature undehisced capsules of Cymbidium aloifolium (L). Sw. were collected from Kolli Hills (Eastern Ghats) of Tamil Nadu, India and stored at $4^{\circ} \mathrm{C}$ for 2 days. These capsules were utilized as seed resource for the further study. Initially it was washed with mild detergent and then soaked in $15 \%(\mathrm{v} / \mathrm{v}) \mathrm{NaOCl}$ augmented with Tween- 80 for $15 \mathrm{~min}$.
Capsules were again washed with fungicide (Bavistin) for 10 min. and subsequently rinsed five times with sterile distilled water. The surface sterilized capsules were longitudinally dissected and around $100 \pm 10$ seeds were transferred into a $200 \mathrm{ml}$ sterile glass jar containing $50 \mathrm{ml}$ of $0.8 \%(\mathrm{w} / \mathrm{v})$ agar-solidified KC, 1/2 MS and VW basal media. Effect of Coconut water $(10 \% \mathrm{v} / \mathrm{v})$ and Peptone $(0.2 \% \mathrm{w} / \mathrm{v})$ were studied in modified KC, 1/2 MS and VW media in which both were supplemented separately. Exact number of seeds was counted under a microscope after the successful transfer.

Plant cultures were maintained at $25^{\circ} \mathrm{C} \pm 2^{\circ} \mathrm{C}$ for $12 \mathrm{~h}$ photoperiod provided by White fluorescent lights, M/s:Philips of 3000 lux intensity. Percentage of germination was calculated using the following formula:

Percentage of Germination $=\frac{X-Y}{X} * 100 \%$

$X=$ Number of seeds inoculated

$\mathrm{Y}=$ Number of seeds germinated

Assessment of suitable conditions for seedling and rooting formation

The KC was used for proliferation of the protocorm based on the obtained result (Table 1). In KC media $2 \%$ of sucrose served as carbon source and additionally two different plant growth regulators (PGRs) namely BAP and NAA were supplemented to each type of medium in different combinations as mentioned in the Table 2 . The $\mathrm{pH}$ of the media was adjusted to 5.3 , followed by an autoclave at $121^{\circ} \mathrm{C}$ for 15 min under 15 $\mathrm{lbs}$ pressure. These cultures were maintained under a $16 \mathrm{~h}$ photoperiod at $25 \pm 2^{\circ} \mathrm{C}$ The experiment was performed in triplicate and average number of shoots per protocorm was determined after four weeks.

For the induction of root, the regenerated multiple shoots of Cymbidium aloifolium were excised and a single shoot was cultured on $\mathrm{KC}$ medium individually fortified with IAA and $\operatorname{IBA}\left(0.5\right.$ to $\left.2.5 \mathrm{mgl}^{-1}\right)$ as mentioned in Table 3 . The observations were recorded with regular intervals of one week up to 16 weeks of culture and the obtained root number and their length was recorded.

Hardening of the seedlings

Well-developed rooted shoots were taken out from the culture vessels and washed under running tap water then the plantlets were washed with fungicide solution. Individual regenerates were placed onto net pots containing equal proportion of charcoal ( $0.5 \sim 1.0 \mathrm{~cm}$ each), brick-gravels and coconut husk as supporting materials. The plantlets were sprayed with 
Table 1 Effect of different media on the germination and protocorm development in Cymbidium aloifolium (L)

\begin{tabular}{|c|c|c|c|}
\hline $\begin{array}{l}\text { Media employed for } \\
\text { seed germination }\end{array}$ & $\%$ of germination & $\begin{array}{l}\text { Time taken for initiation } \\
\text { of germination (days) }\end{array}$ & $\begin{array}{c}\text { Shoot growth } \\
(\%)\end{array}$ \\
\hline $1 / 2 \mathrm{MS}-\mathrm{B}$ & 50 & 85 & 10 \\
\hline $1 / 2 \mathrm{MS}-\mathrm{CW}$ & 30 & 80 & - \\
\hline $1 / 2 \mathrm{MS}-\mathrm{P}$ & 20 & 90 & - \\
\hline $\mathrm{KC}-\mathrm{B}$ & 90 & 65 & 50 \\
\hline $\mathrm{KC}-\mathrm{CW}$ & 80 & 70 & 50 \\
\hline $\mathrm{KC}-\mathrm{P}$ & 70 & 75 & 40 \\
\hline$V W-B$ & - & - & - \\
\hline $\mathrm{VW}-\mathrm{CW}$ & - & - & - \\
\hline $\mathrm{VW}-\mathrm{P}$ & - & - & - \\
\hline
\end{tabular}

B-Basal medium, CW-Coconut Water $(10 \% \mathrm{v} / \mathrm{v})$, P- Peptone $(0.2 \%$, w/v)

Table 2 Effect on BAP and NAA on the development of protocorm into microshoots and regeneration on KC medium

\begin{tabular}{|c|c|c|c|c|}
\hline \multicolumn{2}{|c|}{ Hormone concentration $(\mathrm{mg} / \mathrm{l})$} & \multirow{2}{*}{$\begin{array}{l}\text { Mean number of shoots } \\
(\mathrm{M} \pm \mathrm{SD})\end{array}$} & \multirow{2}{*}{$\begin{array}{l}\text { Mean length }(\mathrm{cm}) \text { of shoots } \\
(\mathrm{M} \pm \mathrm{SD})\end{array}$} & \multirow{2}{*}{$\begin{array}{c}\text { Mean number of roots } \\
(\mathrm{M} \pm \mathrm{SD})\end{array}$} \\
\hline BAP & NAA & & & \\
\hline 0.5 & - & $1.3 \pm 1.34 \mathrm{~lm}$ & $0.72 \pm 0.21 \mathrm{kl}$ & 0 \\
\hline 1.0 & - & $2.0 \pm 1.34 \mathrm{i}$ & $0.54 \pm 0.37 \mathrm{mn}$ & 0 \\
\hline 1.5 & - & $1.4 \pm 1.01 \mathrm{k}$ & $0.57 \pm 0.39 \mathrm{~m}$ & $1.3 \pm 0.64 \mathrm{de}$ \\
\hline 2.0 & - & $1.9 \pm 1.3 \mathrm{ij}$ & $0.80 \pm 0.30 \mathrm{~h}$ & $1.4 \pm 0.48 \mathrm{~cd}$ \\
\hline 0.5 & 0.5 & $2.7 \pm 1.41 \mathrm{gh}$ & $0.73 \pm 0.34 \mathrm{ij}$ & 0 \\
\hline 1.0 & 0.5 & $2.8 \pm 1.46 \mathrm{fg}$ & $1.32 \pm 0.14 \mathrm{de}$ & 0 \\
\hline 1.5 & 0.5 & $4.8 \pm 1.46 \mathrm{~b}$ & $1.46 \pm 0.28 \mathrm{c}$ & $1.6 \pm 0.19 \mathrm{c}$ \\
\hline 2.0 & 0.5 & $3.2 \pm 2.00$ ef & $1.06 \pm 0.55 \mathrm{~g}$ & $1.4 \pm 0.80 \mathrm{~cd}$ \\
\hline 0.5 & 1.0 & $4.5 \pm 1.24 \mathrm{bc}$ & $1.70 \pm 0.15 \mathrm{ab}$ & $2.5 \pm 1.02 \mathrm{~b}$ \\
\hline 1.0 & 1.0 & $6.1 \pm 1.13$ a & $1.79 \pm 0.19$ a & $3.1 \pm 1.64 \mathrm{a}$ \\
\hline 1.5 & 1.0 & $3.8 \pm 0.97 \mathrm{~d}$ & $1.21 \pm 0.31 \mathrm{f}$ & $1.6 \pm 0.66 \mathrm{c}$ \\
\hline 2.0 & 1.0 & $3.4 \pm 1.42 \mathrm{de}$ & $1.40 \pm 0.26 \mathrm{~cd}$ & 0 \\
\hline
\end{tabular}

Table 3 Effect of IAA and IBA on root induction in $\mathrm{KC}$ medium after 25 th day of inoculation

\begin{tabular}{|c|c|c|c|}
\hline Medium+ Hormone (mg/l) & Concentration (mg/l) & Mean root number $(\mathrm{M} \pm \mathrm{SD})$ & Mean root $(\mathrm{cm})$ length $(\mathrm{M} \pm \mathrm{SD})$ \\
\hline \multirow{5}{*}{ IAA } & 0.5 & $1.7 \pm 0.90 \mathrm{~cd}$ & $0.3 \pm 0.35 \mathrm{hi}$ \\
\hline & 1.0 & $2.5 \pm 0.80 \mathrm{c}$ & $0.58 \pm 0.45$ ef \\
\hline & 1.5 & $3.8 \pm 0.97 \mathrm{a}$ & $0.60 \pm 0.38 \mathrm{~cd}$ \\
\hline & 2.0 & $1.4 \pm 0.91 \mathrm{de}$ & $1.74 \pm 0.20$ a \\
\hline & 2.5 & $1.2 \pm 0.60$ ef & $0.41 \pm 0.33 \mathrm{gh}$ \\
\hline \multirow{5}{*}{ IBA } & 0.5 & $2.0 \pm 0.77 \mathrm{c}$ & $0.51 \pm 0.31 \mathrm{fg}$ \\
\hline & 1.0 & $3.8 \pm 0.97$ a & $1.3 \pm 0.13 \mathrm{~b}$ \\
\hline & 1.5 & $1.4 \pm 0.8 \mathrm{de}$ & $0.68 \pm 0.21 \mathrm{e}$ \\
\hline & 2.0 & $0.6 \pm 0.66 \mathrm{~g}$ & $0.26 \pm 0.16 \mathrm{jk}$ \\
\hline & 2.5 & $0.3 \pm 0.64 \mathrm{gh}$ & $0.16 \pm 0.16 \mathrm{bc}$ \\
\hline
\end{tabular}

balanced fertilizers (1 g/l 17N-17P-17k) twice weekly. The transplanted plants were finally kept in the shade house for further acclimatization.

Statistical analysis

Data were recorded on the basis of different parameters subjected to analysis of variance (ANOVA) and mean values of treatments were compared by least significant difference (LSD).

Values are Mean $\pm \mathrm{SD}(\mathrm{n}=10)$ of two independent experiments. Mean values followed by the same letter in a column are not significantly different as indicated by Duncan's multiple range test $(\mathrm{P}=0.05)$. Values within a column having the same alphabet are not statistically significant and sharing at least one letter are no significantly 


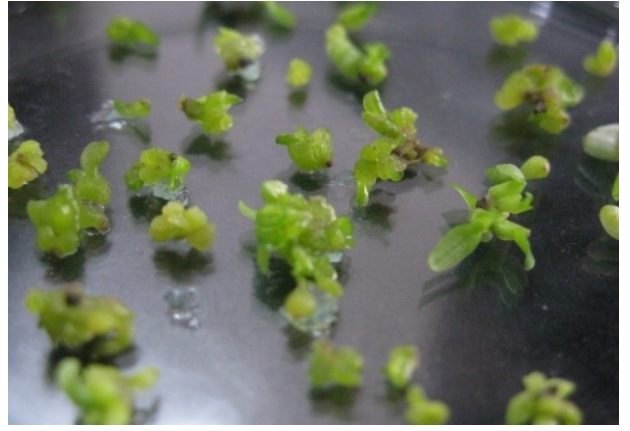

Fig. 1 Protocorm like bodies formation on $\mathrm{KC}-\mathrm{b}$ medium

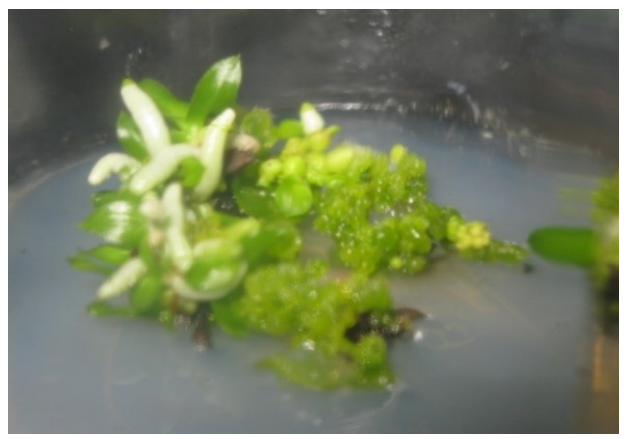

Fig. 2 Regeneration of plantlets and aerial root formation on $1 / 2$ MS medium supplemented with $1.0 \mathrm{mg} / \mathrm{l}$ of BAP and $1.0 \mathrm{mg} / \mathrm{l}$ of NAA

different at $\mathrm{p}<0.05$ level according to Duncan's multiple range test.

\section{Results and Discussion}

The first sign of germination on the $30^{\text {th }}$ day on $\mathrm{KC}$ basal medium was that the embryo turned into spherical form and was enclosed in dark yellow color. After a few days some adventive tissues appeared on their tips and the embryo ruptured at one of the poles and after a few days it showed 4-5fold increases in size with abundant chloroplasts and starch cells. The embryos by the $50^{\text {th }}$ day exhibited a prominent zone of pro-meristematic cells and developed a pair of leaf primordial (Fig. 1).

The well-developed protocorm like bodies (Plbs) were inoculated with $\mathrm{KC}$ media augmented with BAP $(1.0 \mathrm{mg} / \mathrm{l})$ and NAA $(1.0 \mathrm{mg} / \mathrm{l})$ which yields High frequency of plant regeneration (Table 2). One of the primordial developed more rapidly than the other to produce an unequal pair of first embryogenic photosynthetic leaves. Simultaneously with the development of embryonic leaves at the proximal end of the embryo the marginal cells at the distal end of the embryo started giving rise to tubular and unicellular rhizoids.

The seeds are thin and transparent. The cells of seed coats

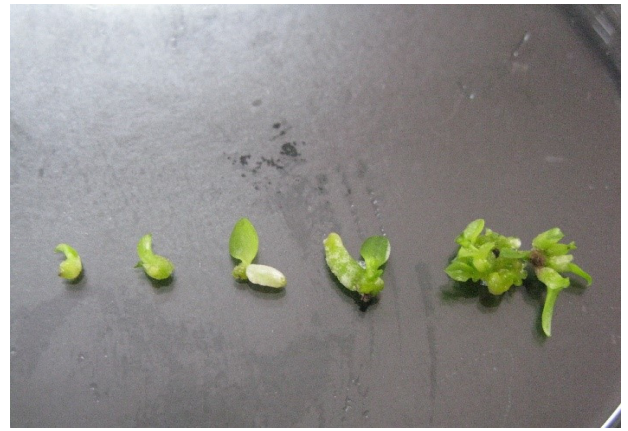

Fig. 3 Different stages of the prtocorm like bodies (PLbs)

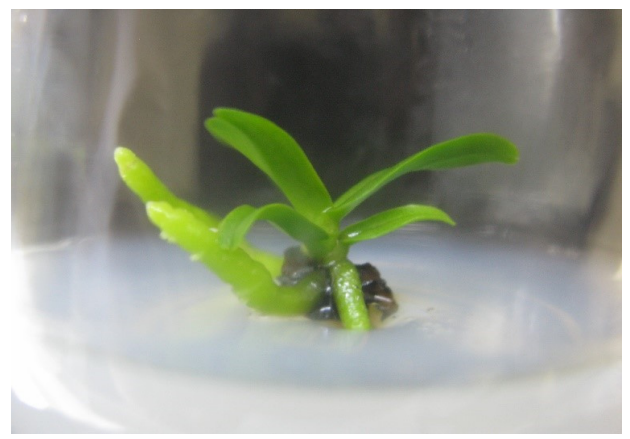

Fig. 4 The seedlings before processed for hardening

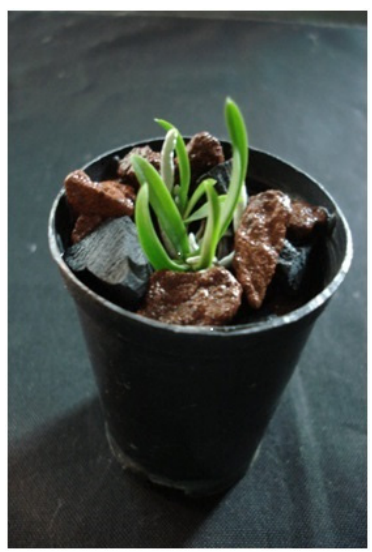

Fig. 5 Potted plant of Cymbidium aloifolium (L)

are varied in size and shape. Such variations that were observed in the present study are in agreement with the observations noted by the previous workers (Clifford \& Smith 1969; Ekanthappa, 1981). It has been earlier established that the nature of seed coat is of great taxonomic value within the Orchidaceae (Stoutamire, 1963, Kalimuthu et al., 2007)).

Thus the early concept that the orchid seeds are sterile and or at least incapable of germination is no more valid (Arditti, 1967). That the germination of seeds of epiphytic orchids posed no problem has been pointed out by various workers (Stoutamire, 1964a; Stoutamire 1964b; Warcap 1971; Mc Intyre et al., 1972; Mc Intyre et al., 1974). However, they have indicated that difficulty was encountered in the germination 
of terrestrial orchid seeds in contrast to those of epiphytic taxa.

The well-developed shoots were removed from the culture tubes and transferred to the rooting media. About $90 \%$ of the shoots rooted well after transfer to the $\mathrm{KC}$ medium supplemented with $0.2 \mathrm{mg} / \mathrm{l} \mathrm{IBA}$.

In the present investigation the developed plantlets were transferred into KC medium supplemented with IAA and IBA separately which was more essential for regeneration of roots. The similar results were obtained in Cymbidium kanran (Shimasaki \& Uemoto 1990) and Dendrobium aqueum (Philip et al., 2009). In Vanda coerulea the rooting efficiency varied with different concentrations of auxin such as IAA, IBA and NAA. The highest percentage of rooting was significant in $1 / 2$ MS medium supplemented with IAA (1.5 mg/l) (Malabadi, 2004, Naing et al., 2010). In 1922, Lewis Knudson at Cornell University reported that the fungus was not required for germination if the seed was sown on agar containing appropriate salts and sugars. Hence Knudson C medium is still being used to germinate the seed of some species supplemented with the specific hormones.

\section{Conclusion}

The present investigation was mainly aimed at understanding the mode of seed germination and organogenesis of the developing seedling. Although different workers have suggested several nutrient media for orchids, three well-known media were tried in the present study to prove into the germination response of seeds selected species. While Knudson C medium promoted the germination of Cymbidium aloifolium better than other media like 1/2 MS and VC.

\section{Acknowledgement}

Authors are grateful to Dr. P. Ponmurugan, Professor and Head, Department of Biotechnology, K. S. R College of Technology, Tiruchengode for his encouragement and Dr. K. S. Rangasamy, Chairman, K. S. R. Group of Institutions for his support.

\section{References}

Arditti J, 1967. Factors affecting the germination of orchid Seeds. Bot. Rev. 33:1-97. Cell Dev. Biol. 28:1-4

Chang C, Chang WC, 2000. Effects of thidiazuron on bud development of Cymbidium sinense Wild in vitro. Plant Growth Regulator. 30:171-175
Clifford H T, Smith WK, 1969. Seed morphology and classification of orchidaceae. Phytomorphology. 19:133-139

Dodds JH, 1997. Introduction; conservation of plant genetic resources - the need for tissue culture; in Dodds JH (Ed) in vitro methods for conservation of plant genetic resources, chapman and Hall, London. pp 1-9

Ekanthappa KG, 1981. Studies in the orchidaceae. Ph.D Thesis. University of Mysore, Mysore, India.

Fay MF, 1994. In what situation is in vitro culture appropriate to plant conservation; Biodiversity and conservation, 3:176-183

Griesbach RJ, 2002 Development of Phalaenopsis Orchids for the Mass-market, Trends in new crops and new uses, J. Janick and A. Whipley Ed., ASHS press, Alexandria, VA

Hey GL, Hey MG, 1966. Raising rare orchids from seeds. In : DE Garmo LR (ed) Proc. 5th World Orchid Conf., pp. 35-38. Long Beach, USA

Jon RJ, Nirmalya B, 2001. Cultural requirements for in vitro seed germination, protocorm growth and seedling development of Geodorum denciflorum (Lam.) Schltr. Indian Journal of Experimental Biology 39:1041- 1047

K. Kalimuthu, R. Senthilkumar and S. Vijayakumar 2007. In vitro micropropagation of orchid, Oncidium sp. (Dancing Dolls), African Journal of Biotechnology Vol. 6 (10), pp 1171-1174

Malabadi RB, Mulgund GS, Nataraja K, 2004. Efficient regeneration of Vanda coerulea, an endangered orchid using thidiazuron. Plant Cell, Tissue and Organ Culture, 76:289-293

Mc Intyre DK, Veitch GJ, Wringley JW, 1972. Australian terrestrial orchid from seed. Amer. Orchid. Soc. Bull. 41:1093-1097

Mc Intyre DK, Veitch GJ, Wringley JW, 1974. Australian terrestrial orchid from seed- II. Improvement in technique and further success. Amer. Orchid. Soc. Bull. 43:52-53

Mohammed R, Kabir TAAB, Rahman M, Hossan S, Khatun Z, Khatun A, Jahan R, 2010. Ethnomedicinal Practices among a Minority Group of Christians Residing in Mirzapur Village of Dinajpur District, Bangladesh, Advances in Natural and Applied Sciences, 4(1):45-51

Naing A.H, Park I S, Hwang Y. J, Chung J. D, and Ki Byung Lim, 2010. In Vitro Micropropagation and Conservation of Rhynchostylis retusa BL, Hort. Environ. Biotechnol. 51(5):440-444

Naing A.H, Myint K. T, Hwang Y.J, Park I.S, Chung J.D, and Lim K.B, 2010. Micropropagation and Conservation of the Wild Medicinal Orchid, Coelogyne cristata, Hort. Environ. Biotechnol. 51(2):109-114

Naing, A.H., Chung, J.D., Park, I.S. et al. Acta Physiol Plant (2011) 33:659

Kee Yoeup Paek, Eun Joo Hahn, and So Young Park, 2011. Micropropagation of Phalaenopsis Orchids via Protocorms and Protocorm-Like Bodies, Plant Embryo Culture: Methods and Protocols, Methods in Molecular Biology, vol. 710:293-306

Philip Robinson J, Balakrishnan V, John Britto S, 2009. In vitro seed germination and protocorm development of Dendrobium aqueum Lindl. A rare orchid species from Eastern ghats of Tamil Nadu, Botany research International (2) 2:99-102

Rao AN, Avadhani PN, 1964. Some aspects of in vitro Culture of Vanda seeds. Proc. 4th world Orchid Cornference, Singapore 
Shimasaki K, Uemoto S, 1990. Micropropagation of a terrestrial Cymbidium species using rhizomes developed from seeds and pseudobulbs. Plant Cell Tiss. Organ Cult. 23:237-244

Shushan S, 1959. Developmental anatomy of an orchid, Catteya Trimos in the Orchids: A scientific survey (Ed. C. L. Withener), Ronald Press, New York

Stoutamire WP, 1963. Terrestrial orchid seedlings. Australian Plants. 2:119-122

Stoutamire WP, 1964a. Terrestrial orchid seedlings - II. Australian Plants. 2:264-26

Stoutamire WP, 1964b. Seeds and seedlings of native orchids. MICH. BOT. 3:107-119

Sandhya B, Thomas S, Isabel W, Shenbagarathai R, 2006. Ethno medicinal plants used by the Valaiyan community of Piranmalai Hills (Reserved Forests) Tamil Nadu, India- a Pilot Study, African Journal of tradictional, Complementary and Alternative Medicine, 3(1):101-114

Songjun Zeng, Weichang Huang, Kunlin Wu, Jianxia Zhang, Jaime A. Teixeira da Silva , and Jun Duan, 2016. In vitro propagation of Paphiopedilum orchids, Crit Rev Biotechnol,
Early Online: 1-14

Tokuhara K, Mii M, 1993. Micropropagation of Phalaenopsis and Doritaenopsis by culturing shoot tips of flower stalk buds. Plant Cell Reports. 13:7-11

Tokuhara K, Mii M, 2001. Induction of embryogenic callus and cell suspension culture from shoot tips excised from flower stalk buds of Phalaenopsis (orchidaceae). In vitro Cell Dev. Biol.-Plant. 37:457-461

Vij SP, 1986. Studies on growth and development of Cymbidium aloifolium Sw. seedlings in vitro. Biology, Conservation and culture of Orchids. pp 423- 427

Villalolos VM, Ferreira P, Mora A, 1991. The use of biotechnology in the conservation of tropical germplasam, Biotech. Adv., 9: 197-215

Warcap JH, 1971. Symbiotic germination of some Australian terrestrial orchids. New Physiol. 72:387-392

Wilkins CP, Bengochea T, Dodds JH, 1982. The use of in vitro methods fore plant genetic conservation, outlook of Agri., 11: $67-72$ 